\title{
STRENGTH ENCOUNTERS OF NON-LOCAL SPEAKERS OF ENGLISH IN US INSTRUCTION DOCTORAL PROJECTS
}

\section{Peressini}

Department Of Pedagogical Science, University Of Malawi, Africa

\section{ABSTRACT}

Global understudies, explicitly non-local speakers of English, comprise a developing populace of the alumni programs in western-based colleges like UK, US, and Australia. Regardless of their report difficulties, these understudies likewise exhibit strength that when properly diverted, could advance their accomplishment in graduate school. The reason for the examination was to investigate the encounters of non-local speakers of English in schooling doctoral projects in US. A subjective exploration, explicitly a phenomenological approach was utilized to investigate the encounters of non-local speakers of English in US doctoral projects in schooling. Members were six doctoral understudies on F1 visa or same. Semi-organized meetings were directed, interpreted, and coded.

KEYWORDS:- Global understudies Non-local speakers of English Education Resilience

\section{INTRODUCTION}

Resilience Experiences of Non-Native Speakers of English in US Education Doctoral Programs by the 2014/15 school year, United States (US) was host to 964,826 worldwide understudies, an expansion of $10 \%$ over the earlier year, and a development of $73 \%$ since the main Global Education Week Briefing held in 2000 (Institute of Global Education [IGE], 2016). As indicated by the 2016 Open Doors report, half of all worldwide understudies come from China, India and South Korea, nations that utilization different dialects separated from English. More than 38,000 of all global understudies have practical experience in instruction and humanities (Hopkins, 2012; Open Doors, 2016).
Global understudies make up $8.2 \%$ of understudy populace in American Psychological Association [APA]-authorize directing brain research programs (Forrest, 2010) and about 1\% in Council for Accreditation of Counseling and Related Educational Programs [CACREP]-certify advising programs (CACREP, 2014) in the US. US is one of the many industrialized nations that profit by the presence of worldwide understudies. Past adding to understudy populace, worldwide understudies offer more than $\$ 30$ billion to the American economy yearly (National Association of Foreign Student Advisers [NAFSA], 2016). In other progressed nations like the United Kingdom, worldwide understudies contribute $£ 10.2$ billion to the economy, the second biggest worldwide market 
after medical care (Heffernan, 2014).

\section{Methods}

The examination utilized a subjective exploration approach. In particular, a phenomenological configuration was utilized to distinguish participants" encounters (Creswell, 2013). This technique was considered proper in light of the fact that the specialists tried to investigate the lived encounters of non-local speakers of English as they explored the interaction of finished a doctoral program in training in a language that was not the same as one they talked consistently and much of the time.

\section{Discussion}

Kimberly figured out how to utilize the experience for her advantage. Having gotten another degree of mindfulness, both of herself and of the climate, she would consistently discover somebody who was not really from her nation to impart her weights to. Her clarification summarizes how bad encounters can be compared with positive ones "... I think I become somewhat more dynamic contrasted with me before. I could effectively discover somebody to converse with on the grounds that I need to soothe my sentiments since it is as of now to an extreme, I can"t hold all".

\section{Conclusion}

Being non-local speakers of English in instruction doctoral program ourselves, we expected to find a few qualities that make this populace strong and make progress toward accomplishment in graduate school. It is conceivable that in searching for topics, we zeroed in on territories that mirror their diligence and not those that show disappointments. We additionally expected that this take a stab at progress would originate from their past encounters either in their nations of origin or when they went to the US. The learned qualities were relied upon to be helpful in their new climate and new jobs as graduate understudies learning in a second or at times third language and contending with individuals who were locals. We at long last expected that in any event, when members recognized occurrences of low confidence, this would push them to prevail as opposed to surrendering. We were additionally conscious of the way that members may not share their dissatisfactions. This was on the grounds that many come from societies where outsiders are not confided in enough to impart issues to.

\section{REFRENCES}

1. Zhu, Y., \& Degeneffe, C. E. (2007). Subjective request and examination configuration: Choosing among five methodologies. (third ed.). Thousand Oaks, CA: Sage Publications Inc. DelgadoRomero, E. A., and Wu, Y-C. (2010). Asian worldwide understudies in advising programs: A gathering mediation to advance social equity. The Journal for Specialists in Group Work, 35(3), 290-297.

2. Wang, C. D. C., \& Heppner, P. P. (2011). Connecting global brain science, proficient fitness, and authority: Counselling therapists as learning accomplices. The Counselling Psychologist, 38(1), 96-121.

3. Poyrazli, S., \& Grahame, K. M (2013). 
CURRENT RESEARCH JOURNAL OF PEDAGOGICS 2(5): 37-39, May 2021

DOI: https://doi.org/10.37547/pedagogics-crjp-02-05-07

ISSN 2767-3278

(C)2021 Master Journals

Crossref dof 81 Google

Accepted 23 $3^{\text {th }}$ May, 2021 \& Published 28 $8^{\text {th }}$ May, 2021

Building an institutional personality in college lunch nooks: The worldwide $\mathrm{PhD}$ understudy insight. Advanced education Research and Development, 33(2), 286296.

4. Nilsson, J. E., \& Dodds, A. K. (2008).

Stressors, uneasiness, assimilation and change among worldwide and North American understudies. Worldwide Journal of Intercultural Relations, 32(3), 244-258. 